\title{
The strontium isotope distribution in water and fish within major South African catchments
}

\author{
LJ Jordaan ${ }^{1,4 *}, V_{\text {Wepener }}^{2}$ and JM Huizenga ${ }^{2,3}$ \\ ${ }^{\prime}$ Council for Geoscience, Private Bag X112, Pretoria, 0001, South Africa \\ ${ }^{2}$ Unit for Environmental Sciences and Management, North West University, Private Bag X6001, Potchefstroom, 2520, South Africa \\ ${ }^{3}$ School of Earth and Environmental Sciences, James Cook University, Townsville, Queensland, 4811, Australia \\ ${ }^{4}$ Department of Zoology, University of Johannesburg, P.O. Box 524, Auckland Park, 2006, South Africa
}

\begin{abstract}
Strontium has 4 naturally-occurring isotopes $\left({ }^{84} \mathrm{Sr},{ }^{86} \mathrm{Sr},{ }^{87} \mathrm{Sr},{ }^{88} \mathrm{Sr}\right.$ ) all of which are stable (Faure, 1986). The correlation between the ${ }^{87} \mathrm{Sr} /{ }^{86} \mathrm{Sr}$ isotope ratio of lake water and fish fin spine tissue was investigated in 23 lakes within 4 major South African catchments. Data showed that fish within a specific lake all have the same Sr isotope ratio in their fin spine tissue regardless of species, age, sex and condition. The origin of the dissolved $\mathrm{Sr}$ fraction in lake water can be either from the natural weathering of upstream geological units or from an upstream anthropogenic source. The $\mathrm{Sr}$ isotopic ratios of the water samples were, however, constant over a multi-year period suggesting that the main source may be the more consistent geological environment. The Sr isotope ratio of river and lake water generally increases along the course of the rivers within the tertiary catchments of the areas investigated. In large rivers like the Vaal, where pollution also plays a role, the pattern is much more complicated. In the Olifants River catchment, Lake Middelburg, Lake Witbank and Lake Doornpoort have a similar Sr isotope ratio, which is distinct from Lake Bronkhorstspruit. Lake Loskop which is downstream from these lakes has a Sr isotope ratio between these two extremes, indicating mixing of water from upstream sources. Similarly Lake Arabie (Flag Boshielo), which is even further downstream, shows a Sr isotope composition between the composition of Lake Loskop and the lakes in the Elands River.
\end{abstract}

Keywords: strontium isotope, ${ }^{87} \mathrm{Sr} /{ }^{86} \mathrm{Sr}$, lake water, fish fin spine, water chemistry, Lake Loskop

\section{INTRODUCTION}

Strontium has 4 naturally-occurring isotopes $\left({ }^{84} \mathrm{Sr},{ }^{86} \mathrm{Sr},{ }^{87} \mathrm{Sr}\right.$, ${ }^{88} \mathrm{Sr}$ ), all of which are stable (Faure, 1986). Strontium isotope ratios have been used in various applications to link biota to their physical environment. Strontium is an ideal element for this purpose as it is present in high concentrations suitable for analytical applications, while $\mathrm{Sr}$ isotope ratios remain independent of biological processes (Capo et al., 1998). The ${ }^{87} \mathrm{Sr} /{ }^{86} \mathrm{Sr}$ ratios of natural materials reflect the source of Sr available during their formation (Capo et al., 1998).

Strontium isotope ratios have successfully been used to link elephant bone and ivory to the environment in which these animals lived (Van der Merwe et al., 1990; Vogel et al., 1990). A similar study linked Sr ratio distribution in modern rodents to geology (Hoppe et al., 1999), while Beard and Clark (2000) showed that the Sr isotope composition of skeletal material can indicate the birthplace and geographic mobility of humans and animals.

Lakes are very special habitats as fish migration and movements are limited by dam walls and usually very shallow waters at the inlets. Adult fish are therefore expected to spend their entire lives within a relatively limited area. Penne and Pierce (2006), in a telemetry study of carp in Clear Lake, Iowa, USA, found that carp congregated in a relatively small area in winter, then moved to specific spawning areas in spring and spread out somewhat during the summer and autumn months. Otis and Weber (1982) showed similar results in a carp telemetry study of the Lake Winnebago system, USA, and indicated that carp in a river system occupy restricted home ranges.

\footnotetext{
* To whom all correspondence should be addressed.

e-mail: wikusj@geoscience.org.za

Received: 17 December 2014; accepted in revised form 16 February 2015
}

It can therefore be hypothesised that bone tissue from fish in South African lakes may have a similar Sr isotope ratio to the aquatic environment they live in. This has been demonstrated in Atlantic salmon from the Connecticut River, Massachusetts, by Kennedy et al. (2002) and in Dolly Varden char from the Yukon Territory by Outridge et al. (2002), using fish otoliths. Strontium is incorporated into bone mass as substituting for calcium in various microcrystalline sites. Palmer and Edmond (1992) state that otolith ${ }^{87} \mathrm{Sr} /{ }^{86} \mathrm{Sr}$ ratios directly reflect dissolved ambient ratios, which in freshwater habitats depend on the geological composition of the catchment. Walther and Thorrold (2006) found in an experimental study of juvenile marine mummichogs (Fundulus heteroclitus) that the water composition and not the food composition determine the isotope composition of $\mathrm{Sr}$ deposited in fish otoliths. Using available South African data (De Villiers et al., 2000; De Villiers and De Wit, 2007), stable geographical distribution patterns in Sr isotope composition of river water can be shown. Douglas et al. (1995) used Sr isotope ratios to link suspended particulate matter in the Murray-Darling River system, Australia, to weathering lithologies in the catchment areas. Preliminary work (Jordaan et al., 2006; Jordaan et al., 2009; Jordaan and Rademeyer, 2009) already indicates a correlation between the $\mathrm{Sr}$ isotope ratio of fish fin spine tissue and lake water in South African lakes.

If only the elemental composition of lake or river water in a large catchment is considered, then the mixing of water from two sub-catchments, which can be described by existing mixing models using the water $\mathrm{Ca} / \mathrm{Sr}$ ratio (Land et al., 2000), may also be reflected in the strontium isotope ratio of fish fin spines. Using the water $\mathrm{Cl}^{-} / \mathrm{SO}_{4}{ }^{2-}$ ratio in a mixing model may similarly add information about possible anthropogenic influences.

The aim of this paper is to investigate the relationship in strontium isotope ratios between different fish species and 
water within selected South African lakes. The study was undertaken to develop a scientific method (forensic tool) to minimize illegal entries at major South African freshwater fishing tournaments (Jordaan, 2015).

\section{MATERIALS AND METHODS}

\section{Description of the project area}

The project area consisted of selected lakes within the Vaal, Mgeni, Crocodile (West) and Olifants River catchments (Fig. 1). The selection criteria were different sizes, different sources of pollution and different underlying geological composition.

\section{Collection and preparation of samples}

Samples included: water taken on the surface of lakes and fish samples taken mainly by bank and boat angling as well as gill netting (Table 1). Water samples for isotope analyses were collected in 2-L high-density polyethylene (HDPE) containers, acidified with ultrapure $\mathrm{HNO}_{3}$, cooled and sent to the laboratory for analyses within $24 \mathrm{~h}$. Water samples for anion and metal concentration analyses were collected in 2-L high-density polyethylene (HDPE) containers, not acidified, cooled and sent to the laboratory for analyses within $24 \mathrm{~h}$.

Four fish species were targeted, i.e., common carp (Cyprinus carpio), sharptooth catfish, (Clarias gariepinus), largemouth bass, (Micropterus salmoides) and Mozambique tilapia (Oreochromis mossambicus), although minor fish species were also included. Fish samples were collected in plastic containers, packed in ice and brought to the laboratory, where they were frozen to $-5^{\circ} \mathrm{C}$.
Fish spines from the dorsal or pectoral fins were removed and dried in an oven at approximately $80^{\circ} \mathrm{C}$ for 14 days. All soft tissues were removed followed by pulverizing in a swing mill.

\section{Chemical analyses}

The analytical method for Sr isotope analysis of water samples consisted of filtering $2 \mathrm{~L}$ samples through $0.45 \mu \mathrm{m}$ cellulose nitrate filters and drying in a drying box to concentrate the Sr. The samples were re-dissolved in $10 \mathrm{~mL}$ concentrated nitric acid and evaporated to dryness in $50 \mathrm{~mL}$ disposable polypropylene beakers on a hotplate $-2 \mathrm{~mL} 6 \mathrm{M} \mathrm{HCl}$ was added, followed by drying on a hotplate. This step was repeated twice to ensure the samples were converted to chlorides. The samples were then centrifuged for $5 \mathrm{~min}$ at $2500 \mathrm{r} / \mathrm{min}$. The samples were purified using $6 \mathrm{~mL}$ Bio-Rad AG50Wx12, 200-400\# cation resin packed in a $10 \mathrm{~mm}$ ID quartz glass column. The resin was cleaned using $30 \mathrm{~mL} 2.5 \mathrm{M} \mathrm{HCl}$. The samples were carefully transferred onto a resin bed, taking care not to disrupt the resin. Hydrochloric acid was passed through the column, collecting $\mathrm{Rb}, \mathrm{Sr}$ and the rare earth element fraction. The purified samples were then analysed for Sr isotope ratios using a Finnigan MAT 261 thermal ionization mass spectrometer. The instrument is controlled by Run It 26X software created by Spectromat (Germany).

The analytical method for Sr isotope analyses of fish fin spine samples consisted of weighing $1 \mathrm{~g}$ of pulverized sample into clean, static-free Savillex beakers; $2 \mathrm{~mL}$ concentrated nitric acid was added such that the samples were thoroughly wetted. 2 $\mathrm{mL} 6 \mathrm{M} \mathrm{HCl}$ was added and the beakers closed with screw caps. The sample was left to dissolve overnight on a hotplate set at

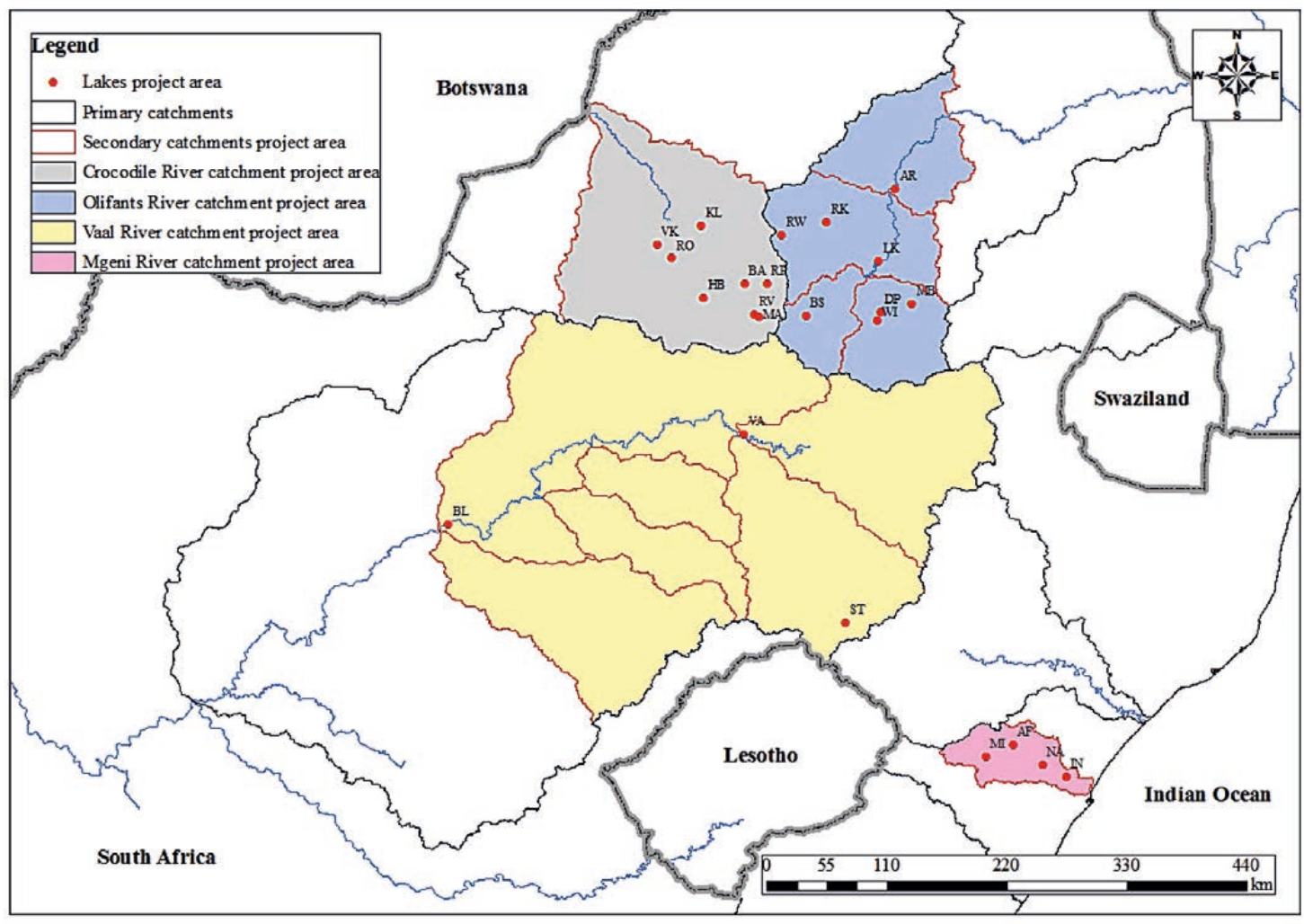

Figure 1

Secondary catchments of the project area. The catchments represented are the Upper Vaal River catchment, the Mgeni River catchment, the Crocodile River (West) catchment and the Upper Olifants River catchment. For codes see Table 1. 
TABLE 1

Codes for the different lakes and fish species are indicated. Numbers in the matrix indicate the number of water and fish Sr isotope ratio analyses per lake. Only fish spine tissue is used. Names in brackets indicate samples taken from rivers. (OL) and (SK) are tributaries of Lake Witbank. (VA) and (VE) are tributaries of Lake Bloemhof. 'No sample' is indicated by 'ns'. Wet season is indicated by ' $w$ '. Dry season is indicated by ' $d$ '. Spine tissue is indicated by 's'. Lake water samples were mainly collected between 2007 and 2009. Fish samples were mainly collected between 2007 and 2011. Both sexes were collected during wet and dry seasons. Water samples were mostly collected independently from fish samples.

\begin{tabular}{|c|c|c|c|c|c|c|c|c|c|c|c|}
\hline \multicolumn{12}{|c|}{ Target components/species } \\
\hline Catchment & Lake/river/ & Code & \multicolumn{2}{|c|}{ Water } & ํㅗㄴ & 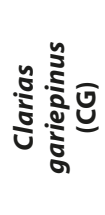 & 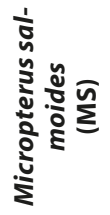 & 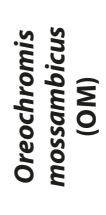 & 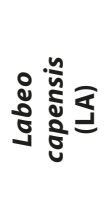 & 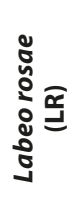 & 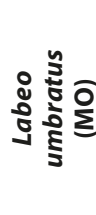 \\
\hline \multicolumn{3}{|l|}{ Season } & $\mathbf{w}$ & d & \multicolumn{7}{|c|}{ Both } \\
\hline \multirow{8}{*}{ 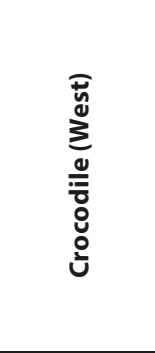 } & Bon Accord & $\mathrm{BA}$ & 2 & $\mathrm{~ns}$ & 1 & $\mathrm{~ns}$ & $\mathrm{n}$ & $\mathrm{ns}$ & $\mathrm{ns}$ & ns & ns \\
\hline & Roodeplaat & $\mathrm{RP}$ & $\mathrm{ns}$ & 4 & $\mathrm{~ns}$ & 1 & $\mathrm{n}$ & 1 & ns & ns & ns \\
\hline & Klipvoor & $\mathrm{KL}$ & 3 & ns & 1 & 1 & $\mathrm{n}$ & ns & ns & ns & ns \\
\hline & Marais & MA & 1 & $\mathrm{~ns}$ & 1 & 1 & $\mathrm{n}$ & ns & ns & ns & ns \\
\hline & Rietvlei & RV & 2 & $\mathrm{~ns}$ & 1 & 1 & $\mathrm{n}$ & $\mathrm{ns}$ & ns & ns & ns \\
\hline & Hartbeespoort & $\mathrm{HB}$ & 3 & ns & 1 & 1 & $\mathrm{n}$ & ns & ns & ns & ns \\
\hline & Roodekopjes & $\mathrm{RO}$ & 3 & $\mathrm{~ns}$ & 1 & 1 & $\mathrm{n}$ & $\mathrm{ns}$ & $\mathrm{ns}$ & ns & ns \\
\hline & Vaalkop & $\mathrm{VK}$ & 3 & $\mathrm{~ns}$ & 1 & ns & $\mathrm{n}$ & $\mathrm{ns}$ & ns & ns & ns \\
\hline \multirow{11}{*}{ 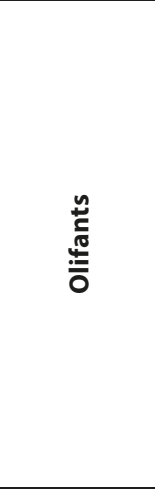 } & Bronkhorstspruit & BS & ns & 3 & 1 & $\mathrm{~ns}$ & 1 & ns & ns & ns & $\mathrm{ns}$ \\
\hline & Olifants River & $(\mathrm{OL})$ & 1 & $\mathrm{~ns}$ & 4 & $\mathrm{~ns}$ & $\mathrm{n}$ & $\mathrm{ns}$ & $\mathrm{ns}$ & $\mathrm{ns}$ & $\mathrm{ns}$ \\
\hline & Steenkool River & (SK) & 1 & $\mathrm{~ns}$ & ns & $\mathrm{ns}$ & $\mathrm{n}$ & ns & ns & ns & ns \\
\hline & Witbank & WI & 2 & 3 & ns & $\mathrm{ns}$ & 3 & $\mathrm{~ns}$ & $\mathrm{~ns}$ & $\mathrm{~ns}$ & $\mathrm{~ns}$ \\
\hline & Doornpoort & $\mathrm{DP}$ & $\mathrm{ns}$ & 3 & 1 & 1 & 2 & ns & ns & ns & ns \\
\hline & Middelburg & $\mathrm{MB}$ & $\mathrm{ns}$ & 3 & ns & $\mathrm{ns}$ & 2 & ns & ns & ns & 1 \\
\hline & Loskop & $\mathrm{LK}$ & $\mathrm{ns}$ & 8 & 50 & 1 & $\mathrm{n}$ & 6 & $\mathrm{~ns}$ & 1 & $\mathrm{~ns}$ \\
\hline & Rust de Winter & RW & 3 & $\mathrm{~ns}$ & 1 & 1 & 1 & ns & ns & ns & ns \\
\hline & Elands River & EL & 1 & $\mathrm{~ns}$ & $\mathrm{~ns}$ & ns & $\mathrm{n}$ & $\mathrm{ns}$ & ns & ns & ns \\
\hline & Rhenosterkop & $\mathrm{RK}$ & 3 & ns & $\mathrm{ns}$ & $\mathrm{ns}$ & $\mathrm{n}$ & 1 & $\mathrm{~ns}$ & ns & ns \\
\hline & Arabie & $\mathrm{AR}$ & ns & 5 & 2 & 1 & ns & $\mathrm{ns}$ & ns & ns & ns \\
\hline \multirow{5}{*}{$\begin{array}{l}\bar{\pi} \\
\overline{7}\end{array}$} & Sterkfontein & ST & 3 & $\mathrm{~ns}$ & $\mathrm{~ns}$ & $\mathrm{~ns}$ & ns & ns & ns & ns & ns \\
\hline & Vaal & $\mathrm{VA}$ & ns & 10 & 9 & 4 & ns & $\mathrm{ns}$ & 4 & $\mathrm{~ns}$ & $\mathrm{~ns}$ \\
\hline & Vaal River & $(\mathrm{VR})$ & 1 & $\mathrm{~ns}$ & ns & ns & ns & ns & ns & ns & ns \\
\hline & Vet River & $(\mathrm{VE})$ & 1 & ns & ns & $\mathrm{ns}$ & ns & ns & ns & ns & ns \\
\hline & Bloemhof & $\mathrm{BL}$ & 9 & ns & 17 & 3 & ns & $\mathrm{ns}$ & $\mathrm{ns}$ & ns & $\mathrm{ns}$ \\
\hline \multirow{4}{*}{ : } & Midmar & $\mathrm{MI}$ & 5 & $\mathrm{~ns}$ & ns & $\mathrm{ns}$ & $\mathrm{ns}$ & $\mathrm{ns}$ & $\mathrm{ns}$ & $\mathrm{ns}$ & $\mathrm{ns}$ \\
\hline & Albert Falls & $\mathrm{AF}$ & 2 & $\mathrm{~ns}$ & ns & ns & ns & ns & ns & ns & ns \\
\hline & Nagle & NA & 2 & $\mathrm{~ns}$ & ns & $\mathrm{ns}$ & ns & $\mathrm{ns}$ & ns & ns & ns \\
\hline & Inanda & IN & 5 & $\mathrm{~ns}$ & 1 & ns & 3 & $\mathrm{~ns}$ & $\mathrm{~ns}$ & ns & ns \\
\hline
\end{tabular}

$95^{\circ} \mathrm{C}$. The samples were removed from the hotplate and allowed to dry to half volume after which another $1 \mathrm{~mL}$ of concentrated nitric acid was added and allowed to dry. A further $2 \mathrm{~mL}$ of $6 \mathrm{M}$ $\mathrm{HCl}$ was added and allowed to dry. This step was repeated twice to ensure the sample was converted to chlorides. The sample was then centrifuged for $5 \mathrm{~min}$ at $2500 \mathrm{r} / \mathrm{min}$. The samples were purified using Bio-Rad AG50Wx12, 200-400\# cation resin, followed by analysis on a Finnigan MAT 261 thermal ionization mass spectrometer.

The analytical method for concentration analyses of Sr and $\mathrm{Ca}$ in water samples consisted of first filtering samples through $0.45 \mu \mathrm{m}$ cellulose nitrate filters (Jordaan and Maritz, 2010). Water samples were then diluted 5 times to add the internal standards (In and Ir) and to reduce total dissolved solids. The samples were made up in $2 \mathrm{ml} / 100 \mathrm{~mL} \mathrm{HNO}_{3}$ to keep analyte elements in solution. Analytical grade $\mathrm{HNO}_{3}$ and ultra-pure water were used in all preparations. Samples were analysed on a Perkin Elmer SCIEX ELAN DRCII ICP-MS with AS 93 plus auto-sampler.

The analytical method for concentration analyses of $\mathrm{Cl}^{-}$ and $\mathrm{SO}^{2-}$ in water samples consisted of first filtering samples through $0.45 \mu \mathrm{m}$ cellulose nitrate filters (Jordaan and Maritz, 2010). Samples were analysed either undiluted or at a dilution factor of 7 times on a Dionex QIC analyser ion chromatograph. The instrument uses an IonPac AG14 $(4 \times 50 \mathrm{~mm})$ and an IonPac AS14 $(4 \times 250 \mathrm{~mm})$ column. 


\section{Quality assurance}

The standard reference material NIST987, used for calibration of the $\mathrm{Sr}$ isotope ratio method, produced the following average ${ }^{87} \mathrm{Sr} /{ }^{86} \mathrm{Sr}$ ratio: 0.710213 , range: $0.709915-0.710414$, standard deviation: $0.000067, n=96$, which is within the published range of $0.71034 \pm 0.00026$. A set of samples were analysed at the University of Cape Town on a NU Instruments MC-ICP-MS for verification. $\mathrm{An}{ }^{87} \mathrm{Sr} /{ }^{86} \mathrm{Sr}$ ratio of $0.710300(n=8)$ was obtained for the reference material. A detection limit of $0.2 \mu \mathrm{g} / \mathrm{L} \mathrm{Sr}, 0.03$ $\mathrm{mg} / \mathrm{L} \mathrm{Cl}^{-}$and $0.10 \mathrm{mg} / \mathrm{L} \mathrm{SO}_{4}{ }^{2-}$ was achieved for concentration analyses of water samples.

To evaluate the method used to determine concentrations in water, liquid samples from the SABS Water-Check (Group 1 and Group 3) inter-laboratory proficiency test (South African Bureau of Standards, 2010a, 2010b, 2010c, 2010d, 2010e, 2010f) were regularly analysed. The elements analysed included $\mathrm{Al}, \mathrm{Ba}, \mathrm{Be}$, $\mathrm{B}, \mathrm{Cd}, \mathrm{Cr}, \mathrm{Co}, \mathrm{Cu}, \mathrm{Fe}, \mathrm{Pb}, \mathrm{Mn}, \mathrm{Hg}, \mathrm{Mo}, \mathrm{Ni}, \mathrm{Si}, \mathrm{Sr}, \mathrm{V}, \mathrm{Zn}, \mathrm{As}$ and Se for Group 1, and chloride and sulphate for Group 3. The average Group $1 z$-scores obtained for this evaluation are as follows: April 2010, 0.73; July 2010, 0.73 and October 2010, 0.69. The average Group $3 z$-scores obtained for this evaluation are as follows: June 2010, 0.77; September 2010, 0.70 and December 2010, 0.60 . All $z$-scores between -2 and 2 are considered satisfactory.

\section{Statistical analyses}

The sample codes used are explained in Table 1. A summary of analytical data for water and fish samples (all species) is listed in Table 2. A one-way ANOVA test was used to assess the correlation of Sr isotope ratios between water and fish from lakes in the project area (Table 2). Similarly, the largest dataset from Lake Loskop fish, as well as the results of a one-way ANOVA test used to assess the correlation in Sr isotope ratios between carp and other fish species within the lake, are listed in Table 3. The Single Factor ANOVA function of the software package Microsoft Office Excel was used for the calculation.

\section{RESULTS AND DISCUSSION}

\section{Sample identification}

In Table 1 the number of species sampled and spine tissues collected for isotope ratio analyses from each lake are represented. The codes provided for the different lakes and fish species are used in all figures and tables. The Olifants River catchment was sampled during both the wet and dry season, while most of the lakes in the other catchments were sampled only during each of the seasons for $\mathrm{Ca}, \mathrm{Sr}$ and anion concentration analyses. For the purpose of this project the period from August to November is considered the dry season and from December to July the wet season.

\section{The Crocodile River catchment}

Figure 2 shows the Sr isotope ratio variation along the Crocodile River system in Gauteng and the North West Province. This system is complicated due to complex geology,

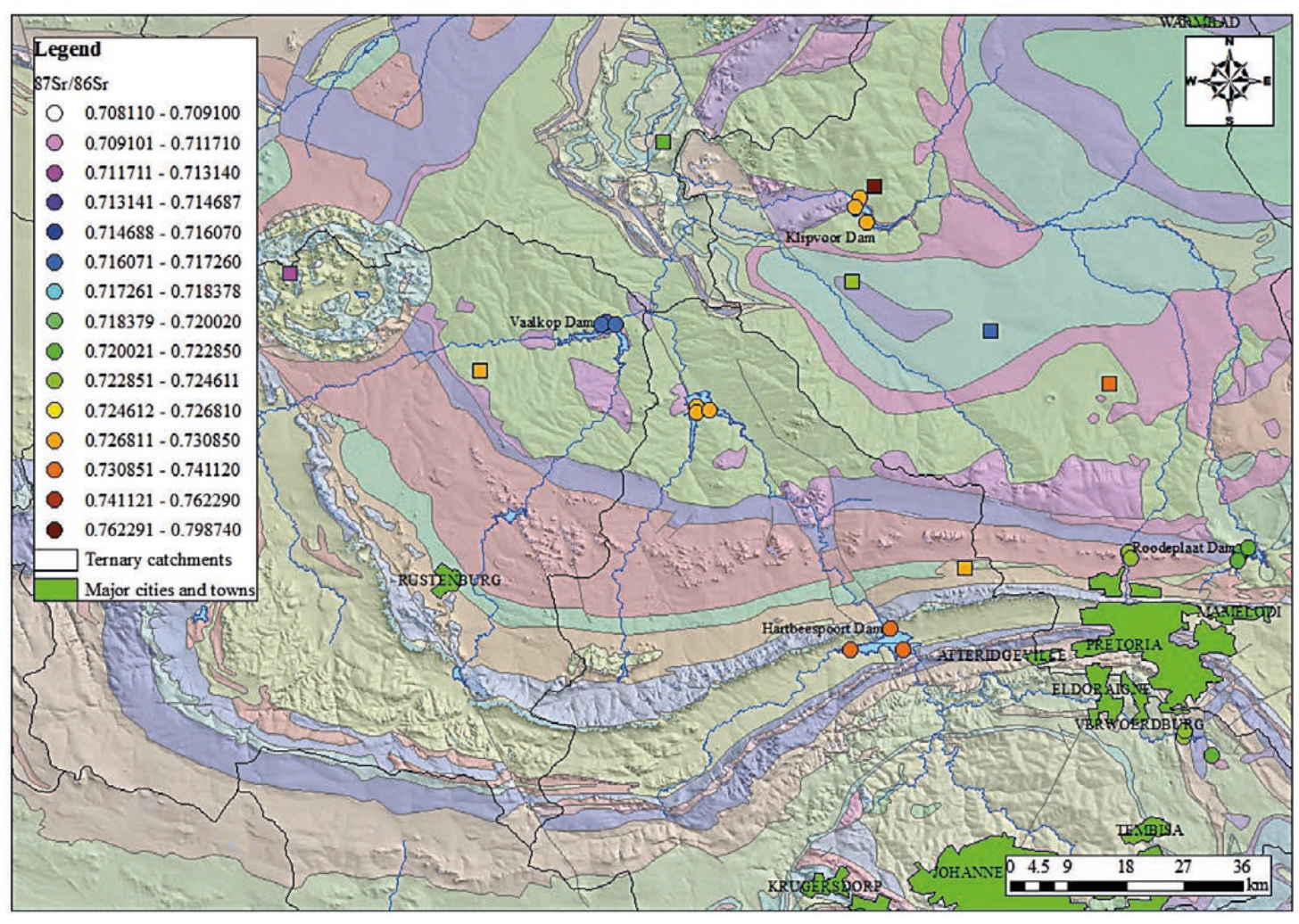

Figure 2

Sr isotope ratios of lake water in the Crocodile River catchment superimposed on the 1:1000 000 scale geology map of South Africa (Council for Geoscience, 2011), draped over the topography. Square symbols show the ${ }^{87} \mathrm{Sr} /{ }^{86} \mathrm{Sr}$ ratio of groundwater from McCaffrey and Willis (2001). The colour of the dots/squares represents the ${ }^{87} \mathrm{Sr}{ }^{\beta 6} \mathrm{~S} r$ isotope ratio as indicated in the legend. Rivers ( $2^{\text {nd }}$ order and higher) and catchments (ternary) are indicated as blue and black lines respectively. 
TABLE 2

Average ( \pm standard deviation) Sr isotope ratio of lake water and fish fin spines (all species) from lakes in the project area. Average ( \pm standard deviation) $\mathrm{Ca}$, Sr and anion content of lake water from the project area. Codes for the lakes and number of samples $(n)$ are explained in Table 1.

\begin{tabular}{|c|c|c|c|c|c|c|c|c|c|}
\hline Catchment & & ake & Water ${ }^{87} \mathrm{Sr} /{ }^{86} \mathrm{Sr}$ & Spine ${ }^{87} \mathrm{Sr} /{ }^{86} \mathrm{Sr}$ & $p$-value & $\mathrm{Cl}(\mathrm{mg} / \mathrm{L})$ & $\mathrm{SO}^{2-}(\mathrm{mg} / \mathrm{L})$ & $\mathrm{Ca}(\mu \mathrm{g} / \mathrm{L})$ & $\operatorname{Sr}(\mu \mathrm{g} / \mathrm{L})$ \\
\hline \multirow{16}{*}{ 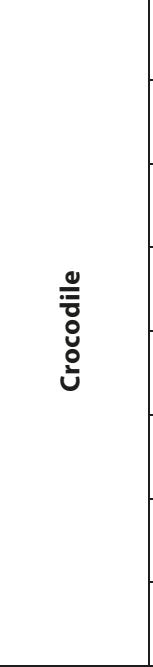 } & \multirow{2}{*}{$\mathrm{BA}$} & Ave & $0.724298 \pm 0.000021$ & 0.725934 & 0.01 & $5.3 \pm 0.1$ & $44.9 \pm 0.1$ & $36734 \pm 34$ & $154.6 \pm 1.2$ \\
\hline & & Range & $0.724277-0.724319$ & & & $35.2-35.4$ & $44.8-45.0$ & $36700-36768$ & $153.4-155.7$ \\
\hline & \multirow{2}{*}{$\mathrm{RP}$} & Ave & $0.721756 \pm 0.000570$ & $0.723950 \pm 0.000357$ & 0.02 & $57.9 \pm 2.3$ & $38.3 \pm 2.3$ & $34258 \pm 333$ & $104.0 \pm 5.9$ \\
\hline & & Range & $0.720788-0.722244$ & $0.723593-0.724308$ & & $55.4-61.5$ & $36.1-42.2$ & $33753-34636$ & $96.4-112.8$ \\
\hline & \multirow{2}{*}{$\mathrm{KL}$} & Ave & $0.729329 \pm 0.000027$ & $0.729945 \pm 0.000023$ & 0.00 & $41.8 \pm 0.2$ & $33.2 \pm 0.3$ & $28960 \pm 185$ & $134.6 \pm 0.8$ \\
\hline & & Range & $0.729296-0.729361$ & $0.729922-0.729968$ & & $41.6-42.1$ & $32.9-33.6$ & $28816-29220$ & $133.7-135.7$ \\
\hline & \multirow{2}{*}{ MA } & Ave & 0.722486 & $0.722950 \pm 0.000387$ & 0.61 & 74.6 & 62.2 & 30981 & 112.3 \\
\hline & & Range & & $0.722564-0.723337$ & & & & & \\
\hline & \multirow{2}{*}{ RV } & Ave & $0.724020 \pm 0.000126$ & $0.723606 \pm 0.000084$ & 0.11 & $45.1 \pm 0.0$ & $42.2 \pm 0.2$ & $28248 \pm 284$ & $99.4 \pm 0.6$ \\
\hline & & Range & $0.723894-0.724146$ & $0.723523-0.723690$ & & $45.1-45.1$ & $42.0-42.3$ & $27964-28532$ & $98.8-99.9$ \\
\hline & \multirow{2}{*}{$\mathrm{HB}$} & Ave & $0.734467 \pm 0.000172$ & $0.734409 \pm 0.000851$ & 0.94 & $50.5 \pm 0.6$ & $42.7 \pm 1.1$ & $35927 \pm 690$ & $139.1 \pm 1.3$ \\
\hline & & Range & $0.734228-0.734628$ & $0.733557-0.735260$ & & $49.7-51.2$ & $41.7-44.1$ & $35260-36877$ & $137.3-140.4$ \\
\hline & \multirow{2}{*}{$\mathrm{RO}$} & Ave & $0.730135 \pm 0.000228$ & $0.730639 \pm 0.000104$ & 0.11 & $67.6 \pm 1.3$ & $57.3 \pm 0.7$ & $35456 \pm 174$ & $154.2 \pm 3.3$ \\
\hline & & Range & $0.729903-0.730446$ & $0.730535-0.730743$ & & $66.5-69.4$ & $56.7-58.3$ & $35302-35698$ & $150.3-158.3$ \\
\hline & \multirow{2}{*}{ VK } & Ave & $0.716612 \pm 0.000420$ & 0.719744 & 0.03 & $101.6 \pm 0.4$ & $80.9 \pm 1.1$ & $36208 \pm 1340$ & $251.3 \pm 6.9$ \\
\hline & & Range & $0.716304-0.717206$ & & & 101.1-102.1 & $80.2-82.4$ & $34581-37862$ & $242.8-259.8$ \\
\hline \multirow{20}{*}{ 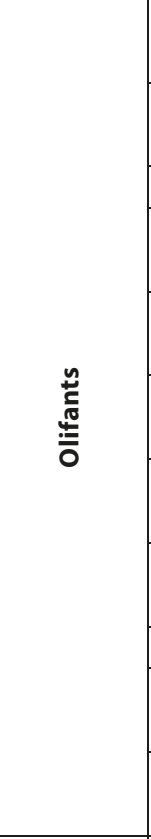 } & \multirow{2}{*}{ BS } & Ave & $0.730204 \pm 0.000080$ & $0.730170 \pm 0.000016$ & 0.67 & $17.6 \pm 0.2$ & $14.5 \pm 1.1$ & $22550 \pm 1343$ & $93.0 \pm 4.8$ \\
\hline & & Range & $0.730093-0.730278$ & 0.730153-0.730186 & & $17.4-17.8$ & $13.7-16.1$ & $21395-24434$ & $89.1-99.7$ \\
\hline & \multirow{2}{*}{$\mathrm{OL}$} & Ave & 0.723241 & $0.722898 \pm 0.000028$ & 0.00 & 12.0 & 56.7 & 22066 & 164.6 \\
\hline & & Range & & $0.722863-0.722929$ & & & & & \\
\hline & SK & Ave & 0.723642 & & & 32.3 & 262.0 & 79573 & 1450.9 \\
\hline & \multirow{2}{*}{ WI } & Ave & $0.725340 \pm 0.000177$ & $0.725666 \pm 0.000206$ & 0.09 & $15.0 \pm 1.4$ & $163.4 \pm 14.0$ & $42398 \pm 1706$ & $343.4 \pm 12.2$ \\
\hline & & Range & $0.725112-0.725583$ & $0.725437-0.725936$ & & $13.0-17.0$ & $150.8-188.7$ & $40272-44771$ & $331.4-364.2$ \\
\hline & \multirow{2}{*}{ DP } & Ave & $0.725551 \pm 0.000111$ & $0.726807 \pm 0.000450$ & 0.01 & $17.6 \pm 0.2$ & $152.9 \pm 0.4$ & $42124 \pm 486$ & $341.3 \pm 1.5$ \\
\hline & & Range & $0.725395-0.725637$ & $0.726275-0.727398$ & & $17.4-17.8$ & $152.3-153.3$ & $41508-42697$ & $339.5-343.1$ \\
\hline & \multirow{2}{*}{$\mathrm{MB}$} & Ave & $0.724975 \pm 0.000262$ & $0.725649 \pm 0.000139$ & 0.03 & $22.0 \pm 0.5$ & $367.1 \pm 13.2$ & $77119 \pm 2299$ & $577.8 \pm 16.3$ \\
\hline & & Range & $0.724611-0.725217$ & $0.725519-0.725841$ & & $21.6-22.7$ & $349.2-380.8$ & $75234-80355$ & $562.9-600.6$ \\
\hline & \multirow{2}{*}{ LK } & Ave & $0.729044 \pm 0.000533$ & $0.730938 \pm 0.000965$ & 0.00 & $14.8 \pm 2.3$ & $148.6 \pm 35.6$ & $36348 \pm 5918$ & $210.1 \pm 29.1$ \\
\hline & & Range & $0.728487-0.730027$ & $0.728734-0.732730$ & & $11.7-17.2$ & $105.0-197.4$ & $27641-46866$ & $166.9-258.0$ \\
\hline & \multirow{2}{*}{ RK } & Ave & $0.746904 \pm 0.000034$ & 0.747130 & 0.04 & $19.8 \pm 0.1$ & $5.5 \pm 0.1$ & $14274 \pm 177$ & $95.7 \pm 0.5$ \\
\hline & & Range & $0.746878-0.746953$ & & & $19.7-20.1$ & $5.4-5.6$ & $14033-14453$ & $95.4-96.5$ \\
\hline & EL & Ave & 0.746191 & & & 11.4 & 5.7 & 7138 & 38.5 \\
\hline & \multirow{2}{*}{ RW } & Ave & $0.745912 \pm 0.000175$ & $0.743131 \pm 0.002406$ & 0.18 & $10.8 \pm 0.0$ & $6.1 \pm 0.1$ & $6825 \pm 117$ & $37.6 \pm 0.2$ \\
\hline & & Range & $0.745670-0.746077$ & $0.740344-0.746215$ & & $10.7-10.8$ & $6.0-6.1$ & $6701-6982$ & $37.4-37.8$ \\
\hline & $\mathrm{AR}$ & Ave & $0.737776 \pm 0.000111$ & $0.737649 \pm 0.000923$ & 0.80 & $31.6 \pm 0.9$ & $114.8 \pm 2.2$ & $36856 \pm 788$ & $211.6 \pm 1.7$ \\
\hline & 101 & Range & $0.737636-0.737935$ & $0.736389-0.738571$ & & $30.4-32.8$ & $112.0-117.2$ & 35 927-38 087 & $209.2-214.3$ \\
\hline & ST & Ave & $0.712373 \pm 0.000006$ & & & 1.2 & 3.1 & $8490 \pm 30$ & $62.8 \pm 0.3$ \\
\hline & 01 & Range & $0.712366-0.712381$ & & & & & $8454-8528$ & $62.4-63.0$ \\
\hline & VA & Ave & $0.713325 \pm 0.001095$ & $0.713546 \pm 0.000622$ & 0.53 & $6.0 \pm 3.1$ & $11.4 \pm 6.6$ & $14529 \pm 3948$ & $90.9 \pm 27.1$ \\
\hline$\overline{0}$ & $8 \pi$ & Range & $0.712485-0.715752$ & $0.712540-0.714877$ & & $2.5-12.2$ & $6.1-27.0$ & $10708-24987$ & $60.4-150.6$ \\
\hline$>$ & VR & Ave & 0.721668 & & & 70.2 & 209.5 & 72259 & 190.2 \\
\hline & VE & Ave & 0.715666 & & & 14.6 & 12.6 & 20930 & 173.1 \\
\hline & BI & Ave & $0.718412 \pm 0.000653$ & $0.718617 \pm 0.000306$ & 0.28 & $34.0 \pm 21.2$ & $79.7 \pm 42.7$ & $29874 \pm 7295$ & $121.3 \pm 52.0$ \\
\hline & | & Range & $0.717728-0.719725$ & $0.717775-0.719280$ & & $9.4-66.8$ & $30.9-145.3$ & $20977-41519$ & $64.0-201.1$ \\
\hline & MI & Ave & $0.712383 \pm 0.000163$ & & & $4.1 \pm 0.1$ & $1.4 \pm 0.2$ & $4375 \pm 556$ & $34.0 \pm 4.0$ \\
\hline & 171 & Range & $0.712174-0.712644$ & & & $4.0-4.2$ & $1.2-1.7$ & $3464-4965$ & $27.2-38.3$ \\
\hline & $\mathrm{AF}$ & Ave & $0.714522 \pm 0.000030$ & & & $6.6 \pm 0.3$ & $2.9 \pm 0.0$ & $4906 \pm 22$ & $34.9 \pm 0.2$ \\
\hline $\bar{c}$ & AГ & Range & $0.714492-0.714552$ & & & $6.3-6.9$ & $2.8-2.9$ & $4884-4928$ & $34.6-35.1$ \\
\hline$\sum^{0}$ & NA & Ave & $0.717628 \pm 0.000015$ & & & $13.5 \pm 0.3$ & 4.3 & $5645 \pm 989$ & $36.5 \pm 6.3$ \\
\hline & $10 \pi$ & Range & $0.717613-0.717642$ & & & $13.2-13.7$ & & $4656-6634$ & $30.3-42.8$ \\
\hline & IN & Ave & $0.718552 \pm 0.000244$ & $0.718489 \pm 0.000628$ & 0.86 & $31.1 \pm 1.3$ & $16.6 \pm 0.7$ & $12674 \pm 1358$ & $64.3 \pm 7.2$ \\
\hline & 110 & Range & $0.718241-0.718923$ & $0.717410-0.718970$ & & $28.8-32.6$ & $15.9-17.5$ & $10058-13940$ & $50.1-69.9$ \\
\hline
\end{tabular}


but in general shows a slight increase in Sr isotope ratios as water moves downstream within tertiary catchments. Lake Roodekopjes is inconsistent with this pattern, as it has a slightly lower value than Lake Hartbeespoort, which is approximately $50 \mathrm{~km}$ upstream. The Lake Vaalkop tertiary catchment contains the Pilanesberg alkali intrusive complex which is different in both composition and age to the geology of the Lake Hartbeespoort/Roodekopjes system. This may explain the very distinct $\mathrm{Sr}$ ratio of the Lake Vaalkop water.

\section{The Olifants River catchment}

The Sr isotope ratio of water samples from different localities in the Olifants River catchment shows a very distinct pattern (Fig. 3). Water within tertiary catchments of the Olifants River system generally shows a slight increase in the ${ }^{87} \mathrm{Sr} /{ }^{86} \mathrm{Sr}$ isotope ratio downstream. When water from two different tertiary catchments is combined the Sr isotope ratio shows an intermediate value between the values of the two sources. In the Olifants River catchment, water from the Witbank and Middelburg sub-catchments is similar. When combined with water from the Bronkhorstspruit sub-catchment the intermediate ratios of Lake Loskop result. Lakes in the Elands River catchment have much higher Sr ratios than that of the Olifants River catchment and result in the intermediate $\mathrm{Sr}$ isotope ratio of water in Lake Arabie, located downstream of the confluence of the two systems. Figure 3 shows that catchments with similar geology produce similar isotope ratios in the rivers that drain them, while different geology can produce quite distinct Sr ratios in others.

\section{The Orange/Vaal River catchment}

Figure 4 shows the Sr isotope ratios in the massive Orange/Vaal River system (some data from De Villiers et al., 2000; De Villiers and De Wit, 2007). When looking at the Upper Orange and Caledon River catchment a similar pattern emerges, with a slight increase in the Sr isotope ratio within tertiary catchments. This part drains the relatively uncomplicated Karoo stratigraphy and is very similar to the Mgeni River which drains eastwards from the same Karoo stratigraphy. The Lower Orange River shows a mixed ratio of water from the Upper Orange and the Vaal Rivers. Further downstream, variation in $\mathrm{Sr}$ isotope ratios is limited to confluences of major tributaries.

The Vaal River (Fig. 4) shows the most complicated and varied Sr isotope ratio pattern of all the systems investigated. In this case smaller sub-catchments need to be evaluated to follow the variation in $\mathrm{Sr}$ isotope ratios. Figure 5 shows the Vaal River from Lake Vaal in the east to Lake Bloemhof in the west. The map indicates $2^{\text {nd }}$ and higher order rivers as well as tertiary catchments. Lake Vaal is very large and has two inlets. There is a clear difference in Sr isotope ratios of water from the Vaal River side versus the Wilge River side. Water is well mixed in the western part of the lake closest to the dam wall. The Vaal River between Lake Vaal and Lake Bloemhof shows a large variation in Sr isotope ratios. This is mostly related to the large number of tributaries joining the Vaal River in this area. Tributaries have very distinct $\mathrm{Sr}$ isotope ratios, possibly related not only to the underlying geology but also to industrial pollution from the Vereeniging and Vanderbijlpark areas. Lake Bloemhof (Fig. 5) also has two inlets but seems to be dominated by the Vaal River as it has a higher flow rate than the Vet River. The Vet River does have a distinct $\mathrm{Sr}$ isotope ratio $10 \mathrm{~km}$ upstream from Lake Bloemhof.

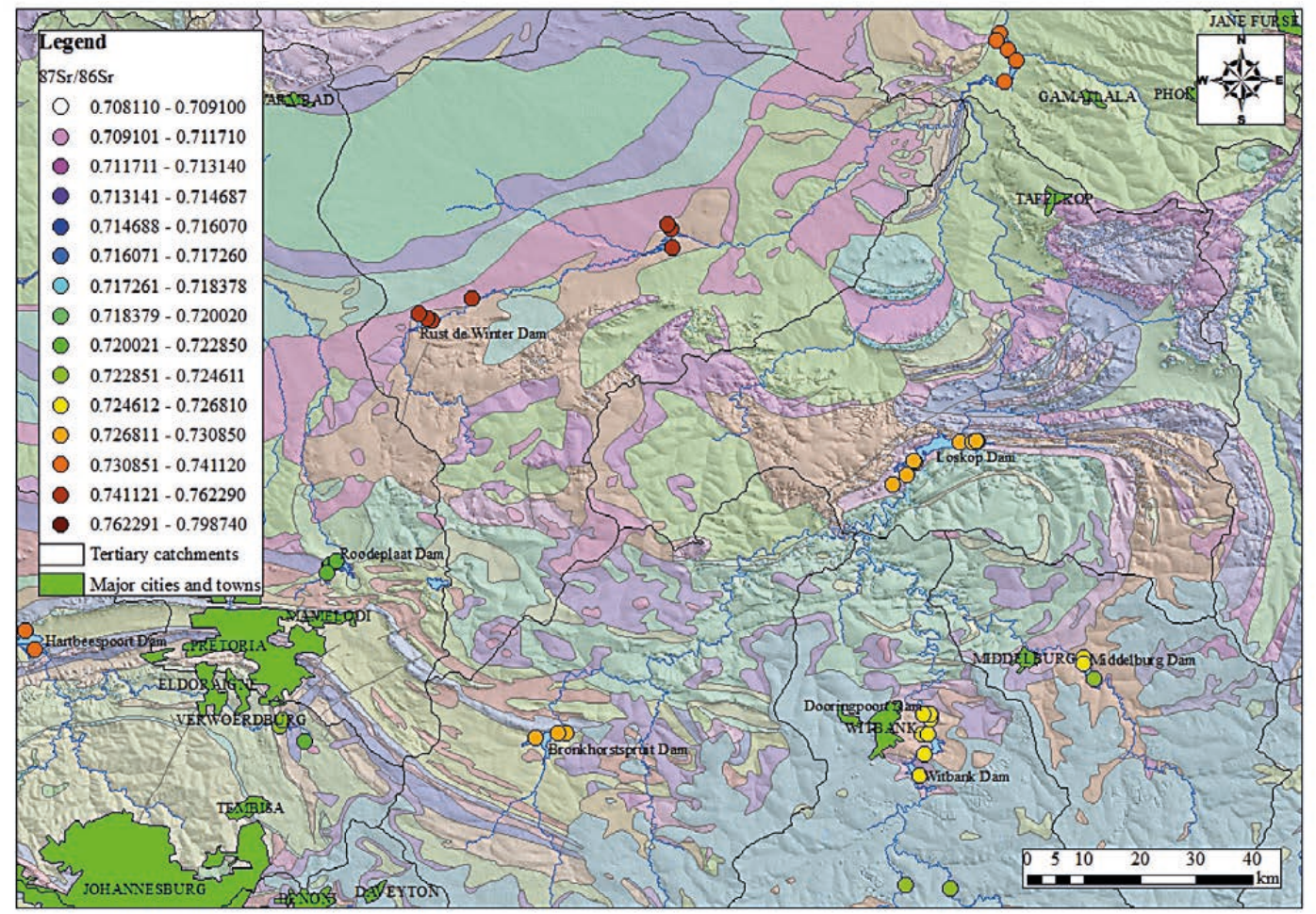

Figure 3

Sr isotope ratios of lake and river water in the Olifants River catchment superimposed on the 1:1 000000 scale geology map of South Africa (Council for Geoscience, 2011), draped over the topography. The colour of the dots represents the ${ }^{87} \mathrm{Sr}{ }^{86} \mathrm{~S}$ r isotope ratio as indicated in the legend. Rivers (2nd order and higher) and catchments (ternary) are indicated as blue and black lines respectively. 


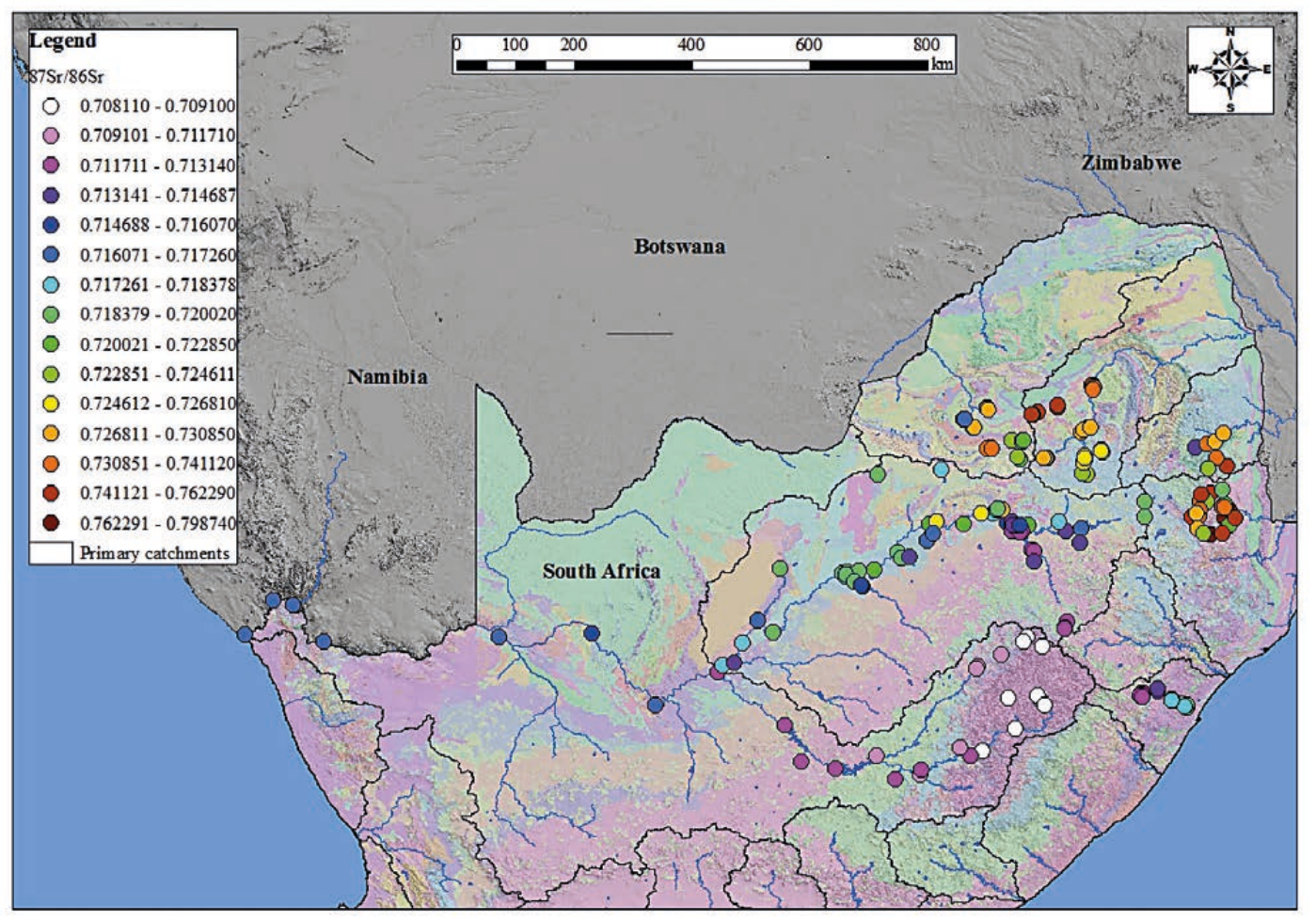

Figure 4

Sr isotope ratios of lake and river water in the Orange/Vaal, Crocodile, Olifants and Mgeni River catchments, superimposed on the 1:1 000000 scale geology map of South Africa (Council for Geoscience, 2011), draped over the topography. Some data from the Orange/Vaal catchment from De Villiers et al. (2000). Swaziland data from De Villiers and De Wit (2007). The colour of the dots represents the ${ }^{87} \mathrm{Sr}{ }^{86} \mathrm{Sr}$ isotope ratio as indicated in the legend. Rivers and catchments are indicated as blue and black lines, respectively.

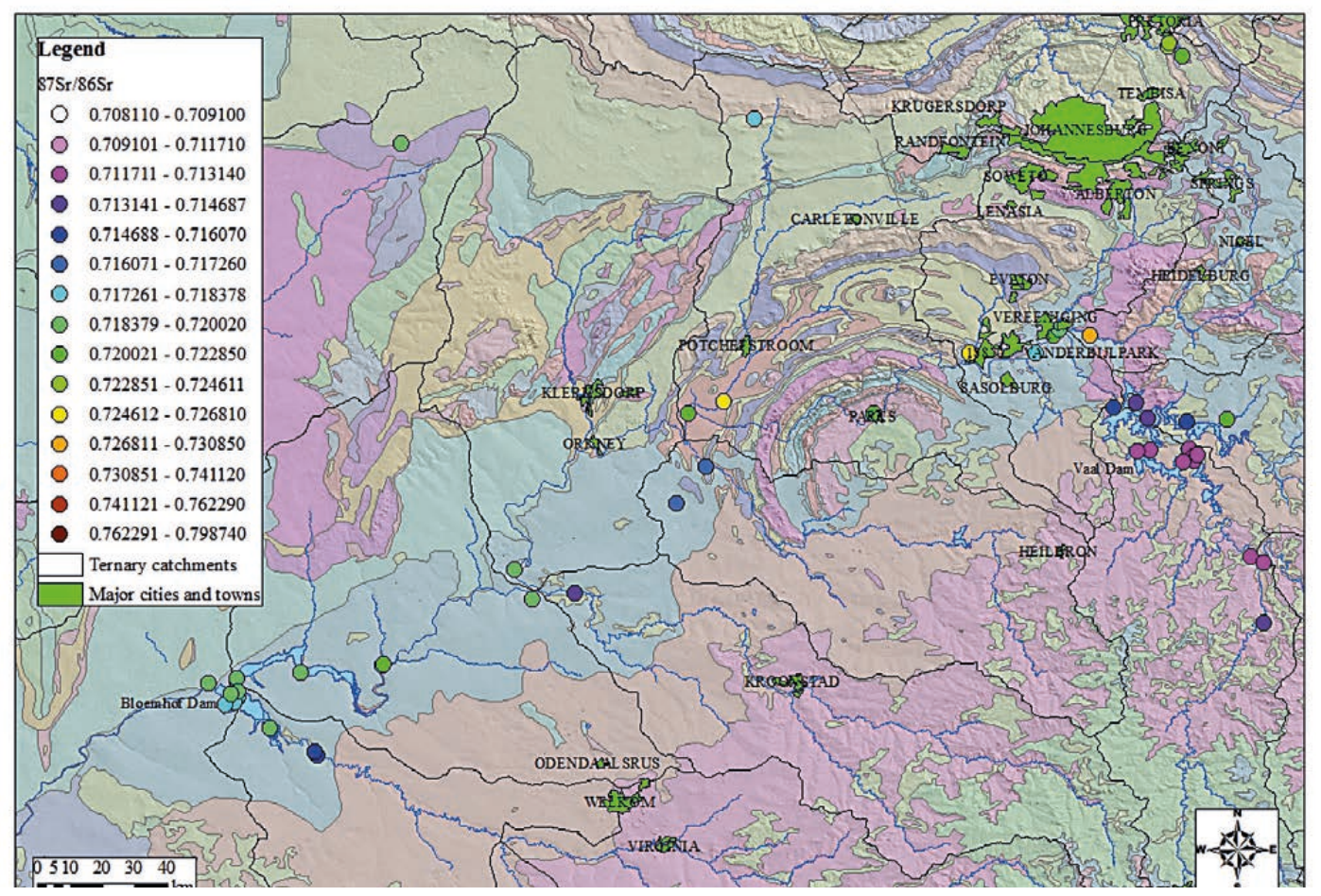

Figure 5

Sr isotope ratios of water in Lake Vaal and Lake Bloemhof superimposed on the 1:1 000000 scale geology map of South Africa (Council for Geoscience, 2011), draped over the topography. Some data from the Orange/Vaal catchment from De Villiers et al. (2000). The colour of the dots represents the ${ }^{87} \mathrm{Sr}{ }^{\beta 6} \mathrm{Sr}$ isotope ratio as indicated in the legend. Rivers ( $2^{\text {nd }}$ order and higher) and catchments (ternary) are indicated as blue and black lines, respectively. 


\section{The Mgeni River catchment}

Figure 6 shows the Sr isotope ratios of water from 4 lakes within the Mgeni River in KwaZulu-Natal. This system appears much simpler as it is contained within one tertiary catchment which shows a slight increase in Sr isotope ratios moving downstream from Lake Midmar towards Lake Inanda. The river is approximately $130 \mathrm{~km}$ long and passes over several distinct geological units which may contribute to the Sr isotope ratio of the river water.

\begin{tabular}{|c|c|c|c|c|}
\hline \multicolumn{5}{|c|}{$\begin{array}{c}\text { TABLE } 3 \\
\text { Average ( } \pm \text { standard deviation) Sr isotope ratio of spine } \\
\text { tissue from different fish species sampled in Lake Loskop. } \\
\text { Other species are compared to carp (CC). Significance } \\
\text { regarded as } p<0.05 \text {. For codes see Table } 1 \text {. }\end{array}$} \\
\hline Lake & Spe & & Spine ${ }^{87} \mathrm{Sr} /{ }^{86} \mathrm{Sr}$ & $p$-value \\
\hline \multirow{10}{*}{ LK } & \multirow{3}{*}{$\mathrm{CC}$} & Average & $0.730928 \pm 0.000953$ & \\
\hline & & Range & $0.728923-0.732730$ & \\
\hline & & $n$ & 42 & \\
\hline & \multirow{2}{*}{ CG } & Average & 0.728734 & 0.03 \\
\hline & & $n$ & 1 & \\
\hline & \multirow{3}{*}{$\mathrm{OM}$} & Average & $0.731388 \pm 0.000632$ & 0.27 \\
\hline & & Range & $0.730440-0.732303$ & \\
\hline & & $n$ & 6 & \\
\hline & \multirow{2}{*}{ LR } & Average & 0.730879 & 0.96 \\
\hline & & $n$ & 1 & \\
\hline
\end{tabular}

\section{Fish}

Data obtained during the project indicated a correlation (although not in all cases statistically significant), between the ${ }^{87} \mathrm{Sr} /{ }^{86} \mathrm{Sr}$ isotope ratio of fish spine tissue and the lake water in which the fish lived while developing these tissues (Table 2). In the Mgeni and Orange/Vaal River catchments the Sr ratio of fish and water were statistically the same. In the Olifants and Crocodile River catchments population sizes were too small for comparison, except at Lake Loskop where the Sr ratios of fish and water were statistically different. In Lake Loskop the Sr ratios of different fish species were not significantly different (Table 3).

When plotting the average ${ }^{87} \mathrm{Sr} /{ }^{86} \mathrm{Sr}$ ratios of fish spine tissue against the average ${ }^{87} \mathrm{Sr} /{ }^{86} \mathrm{Sr}$ ratios of water (Fig. 7), a significant linear regression $(r=0.98, p<0.005)$ was obtained. The error bars indicate the total range of values for each locality. The range of values for water samples from any specific lake is generally smaller than the range of values for fish samples from that same lake. It is, however, not influenced by the specific fish species (Table 3), the sex of the fish, the age of the fish and the season in which the fish were caught, as fish were collected from both sexes, both seasons and different ages, yet still produced a limited range of $\mathrm{Sr}$ isotope ratios for each lake. The Sr ratios were in some cases determined over a 4 -year period in which time there were no significant changes in these ratios (Table 1).

Fish spine tissue from Lake Rust de Winter showed a relatively large variation in ${ }^{87} \mathrm{Sr} /{ }^{86} \mathrm{Sr}$ ratio, while the water had a relatively small range. It is not clear what causes this large range in fish spine tissue data or why most of the data plot below

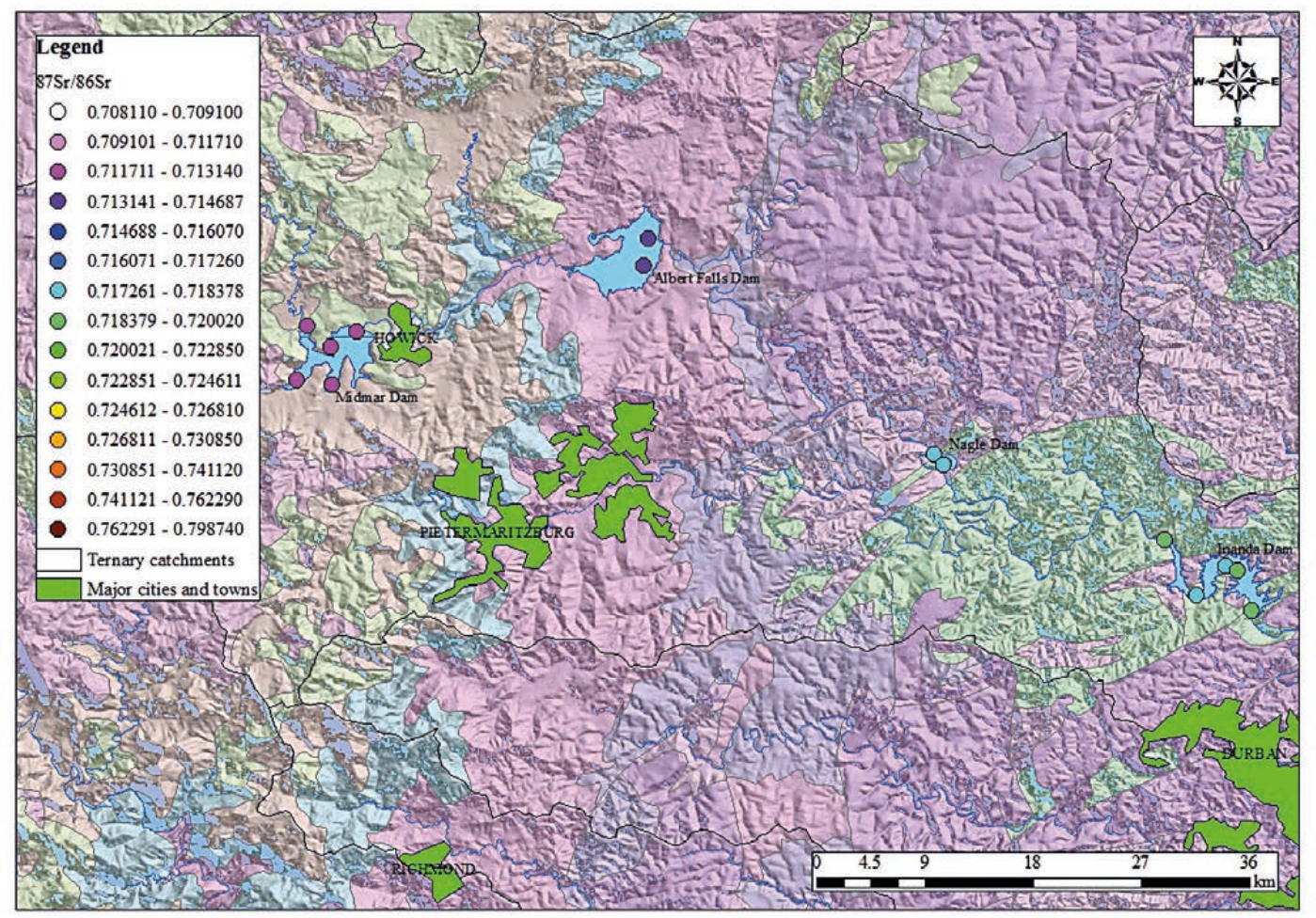

Figure 6

Sr isotope ratios of lake water in the Mgeni River catchment superimposed on the 1:1 000000 scale geology map of South Africa (Council for Geoscience, 2011), draped over the topography. The colour of the dots represents the ${ }^{87} \mathrm{Sr} /{ }^{86} \mathrm{Sr}$ isotope ratio as indicated in the legend. Rivers (2 ${ }^{\text {nd }}$ order and higher) and catchments (ternary) are indicated as blue and black lines, respectively. 
the regression line in Fig. 7. Samples from Lake Loskop, Lake Roodeplaat, Lake Bon Accord and Lake Doornpoort all plot slightly above the regression line in Fig. 7. Even though only a limited number of spine samples were analysed from each individual lake, the data range for each lake indicates that this shift in the data may be real and not related to an analytical artefact.

The relatively large spread in data from Lake Vaal (Fig. 7) is due to a difference in Sr isotope ratios between the Vaal and the Wilge Rivers that feed the lake. Fish were mainly collected during fishing competitions at the Jim Fouché resort on the Wilge River inlet side, although sampling was not restricted to this area. Lake Bloemhof shows a similar situation although the lake is dominated by the Vaal River.

\section{Influence of inter-catchment water transfers on $\mathrm{Sr}$ isotope ratios}

Middleton and Bailey (2005) describe 28 major inter-catchment water transfer schemes for South Africa. These systems include domestic and industrial water supply schemes, hydro-electric power generation schemes and irrigation schemes. These systems either transport water directly from one catchment to another or transport water for domestic or industrial use that reaches destination rivers as waste water (DWAF, 2004).

The most significant of these schemes is water from the Lesotho Highlands Project which is transferred into the Vaal River catchment and then pumped from Lake Vaal to Johannesburg and Pretoria to end up in the Crocodile River catchment. Water from the Lesotho mountains has a distinctly low ${ }^{87} \mathrm{Sr} /{ }^{86} \mathrm{Sr}$ isotope ratio (0.709) compared to other more local Lake Vaal tributaries (0.715) (Fig. 4). Therefore the Wilge River side of Lake Vaal, where the water from Lesotho is received, also has a lower ${ }^{87} \mathrm{Sr} /{ }^{86} \mathrm{Sr}$ isotope ratio than the Vaal River side.

Water is also transferred to the Olifants River catchment to supply coal-fired power stations in the Upper Olifants River region. This water is, however, not returned to the Olifants River system (Van der Merwe, 2011). These pumping schemes should therefore contribute in some degree to the chemical characteristics of the water in rivers and lakes in South Africa. The amount of water displaced through these schemes is, however, relatively constant and should therefore have a constant

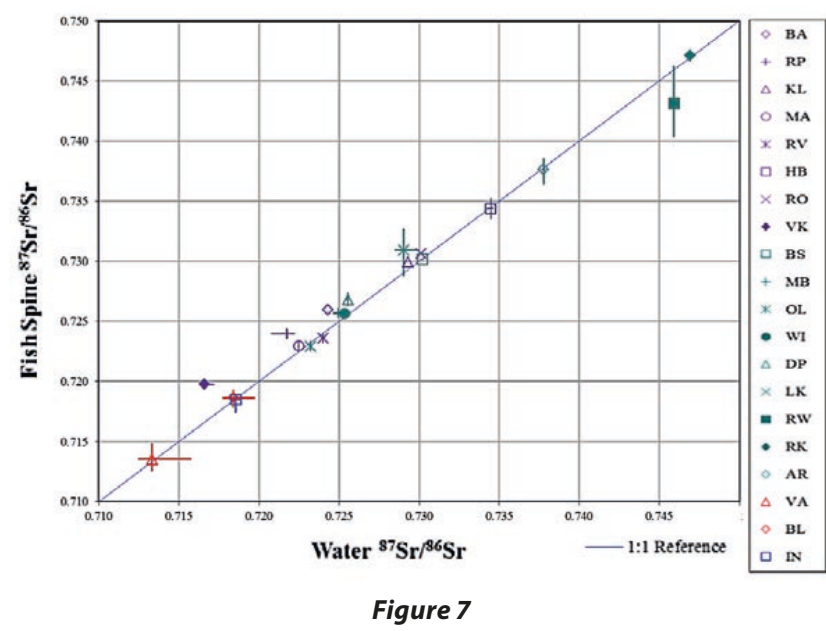

Average Sr isotope ratios of water and fish from the project area. Solid line indicates 1:1 reference line. A linear regression of all data produced a $R^{2}$ value of 0.98 , whether forced through zero $(y=1.00 x)$ or not $(y=0.93 x+0.05)$. Error bars indicate total range of data for each locality. For codes see Table 1. influence on the natural water chemistry. Correlating fish to lake water should therefore be possible despite the fact that the water may contain significant anthropogenic components.

\section{Geological significance and Sr isotope ratios}

If $\mathrm{Rb}$ and $\mathrm{Sr}$ are incorporated into rock at its formation and the system remains closed, the amount of ${ }^{87} \mathrm{Sr}$ increases over time as radioactive ${ }^{87} \mathrm{Rb}$ decays. Older rocks will therefore, in general, have higher ${ }^{87} \mathrm{Sr} /{ }^{86} \mathrm{Sr}$ ratios than younger rocks with the same initial $\mathrm{Rb} / \mathrm{Sr}$ ratio (Capo et al., 1998). The utility of the $\mathrm{Rb}-\mathrm{Sr}$ isotope system results from the fact that different minerals in a given geological setting can have distinctly different ${ }^{87} \mathrm{Sr} /{ }^{86} \mathrm{Sr}$ ratios as a consequence of different ages, original $\mathrm{Rb} / \mathrm{Sr}$ values and the initial ${ }^{87} \mathrm{Sr} /{ }^{86} \mathrm{Sr}$ ratios. Strontium derived from minerals through weathering reactions will have the same ${ }^{87} \mathrm{Sr} /{ }^{86} \mathrm{Sr}$ as the initial mineral. Differences in ${ }^{87} \mathrm{Sr} /{ }^{86} \mathrm{Sr}$ in catchment waters will therefore either depend on differences in mineralogy along contrasting flowpaths or on the relative amounts of $\mathrm{Sr}$ weathered from the same suite of minerals (Kendal et al., 1995). According to Faure (1986) Rb-bearing minerals are generally more resistant to weathering than Sr-bearing minerals. Strontium is therefore more readily lost from rocks exposed to weathering than $\mathrm{Rb}$ and the ${ }^{87} \mathrm{Sr} /{ }^{86} \mathrm{Sr}$ ratio of $\mathrm{Sr}$ that goes into solution is generally lower than the ${ }^{87} \mathrm{Sr} /{ }^{86} \mathrm{Sr}$ ratio of the unweathered rock. Faure (1986) does however note exceptions to this generalization.

Figure 4 shows $4^{\text {th }}$ and higher order rivers superimposed on the 1:1 000000 geology map of South Africa. When evaluating the regional systems, it is noted that the origins of the Caledon, Orange, Mgeni and Wilge Rivers are all situated in the middle and upper regions of the Drakensberg. In all of these rivers a very similar Sr isotope pattern emerges, regardless of the direction in which the river drains (some data from De Villiers et al., 2000). These rivers originate in or close to the Drakensburg basalts, then flow into older successions of the Karoo sedimentary sequence until they finally reach significantly older basement lithologies. The ${ }^{87} \mathrm{Sr} /{ }^{86} \mathrm{Sr}$ ratios of water samples increase from approximately 0.709 at the top to 0.715 at the base of the Karoo sequence. Where the Vaal River drains lithologies older than the Karoo sediments it has a Sr ratio of approximately 0.715 to 0.720 , which is maintained in the Lower Orange River. There are however many local variations to this pattern. Fisher and Strueber (1976) found a similar situation in the Susquehanna River and its tributaries that drain large areas of Pennsylvania and Maryland in the USA. They observed that the ${ }^{87} \mathrm{Sr} /{ }^{86} \mathrm{Sr}$ ratio varies irregularly along the river as a result of mixing with water from tributaries. Pollution from anthropogenic sources may play a role in portions of the Vaal River, but this is likely a minor contributor to the Sr ratio of a large river. Several inter-catchment water transfers to and from the Vaal River may also contribute to a more irregular $\mathrm{Sr}$ isotope pattern.

The Swaziland rivers show a very complex pattern as they drain a very complicated geology (data from De Villiers and De Wit, 2007). The patterns are very different from the rivers draining the Drakensberg lavas and sediments. Primary river water in an area subject to active erosion will show a much closer relationship with the geology than massive rivers that flow for hundreds of kilometers and show only average Sr isotope ratios.

The Crocodile River system (Fig. 2) originates mostly in the Transvaal sediments and then continues through the Bushveld complex. This gives all the tributaries a similar Sr isotope ratio. Lake Vaalkop has two inlets and is very different to the rest of the system. The Hex River (southern inlet) is similar to the rest 
of the catchment but the Elands River (western inlet) originates near the Pilanesberg alkali complex. This may contribute to the much lower Sr isotope ratio of Lake Vaalkop. The Crocodile River system is also the destination of inter-catchment water transfers from Lake Vaal. This may contribute to the difference between water that originates locally and water that has a larger component of water from Lake Vaal.

In the Olifants River catchment (Fig. 3), tributaries originate in, geologically, very distinctive sequences. The Middelburg and Witbank sub-catchments originate in the older portions of the Karoo sequence and are very different from the Bronkhorstspruit sub-catchment, which originates in mostly Transvaal sequence lithologies. This can clearly be seen in the $\mathrm{Sr}$ isotope ratios, which combine to give Lake Loskop an intermediate $\mathrm{Sr}$ isotope ratio. The Elands River originates in the Bushveld igneous complex and is very different from the Olifants River. The Sr isotope ratio of the Elands River is therefore higher (0.747) than the water in Lake Loskop (0.729). A mixing of these sources results in the Sr ratio of 0.738 at Lake Arabie further downstream (Table 2). The Sr isotope ratio of water in a river system is therefore mostly determined by the geology at the origin of the river were most weathering occurs (De Villiers et al., 2000). Further downstream it is determined by the contributions from tributaries which gain their Sr isotope ratio in a similar fashion. Sr isotope data from rocks in the upper catchment of the Olifants River are limited. Barton et al. (2004) investigated Sr isotope ratios in glauconite from quartzrich sediments of the Witbank coalfield above the Number 4 and Number 5 coal seams. The ${ }^{87} \mathrm{Sr} /{ }^{86} \mathrm{Sr}$ ratios ranged from 0.751 to 0.922 for glauconite from the Vryheid formation, from 1.165 to 1.241 for coarse-grained detrital muscovite, and was 1.201 for coarse-grained detrital biotite from strata closely associated with the glauconite-bearing beds.

Published Sr isotope data from global lakes and rivers is very limited. Comparing the Sr isotope data from South African rivers on a mixing diagram (Fig. 8) to the limited amount of data from international examples listed by Faure (1986), Edmond (1992), Harris et al. (1998), Galy et al. (1999), Dalai et al. (2003), Négrel et al. (2004) and De Villiers and De Wit (2007), it can be seen that the Olifants and Crocodile River systems correspond to rivers draining the Himalayas, while the Orange/Vaal and Mgeni River systems fall within the field of global rivers. De Villiers and De Wit (2007) noted that rivers draining Swaziland also correspond to Himalayan examples. Rivers draining catchments dominated by K-granites have higher ${ }^{87} \mathrm{Sr} /{ }^{86} \mathrm{Sr}$ ratios (average 0.767) while Achaean Na-rich gneisses (average 0.731 ) and volcano-sedimentary sequences (average 0.735 ) have lower values. Edmond (1992) concluded that the average fluvial ${ }^{87} \mathrm{Sr} r{ }^{86} \mathrm{Sr}$ ratio (excluding Himalayas) is 0.710 .

A linear correlation on a mixing diagram is typical of many river systems where a high $\mathrm{Sr}$, low ${ }^{87} \mathrm{Sr} /{ }^{86} \mathrm{Sr}$ end member, derived from carbonate, is mixed with a low $\mathrm{Sr}$, high ${ }^{87} \mathrm{Sr} /{ }^{86} \mathrm{Sr}$ end member, derived from silicate (Palmer and Edmond, 1992).

The Mgeni River system shows a gradual increase in the $\mathrm{Sr}$ isotope ratio as well as in the Sr content moving downstream from Lake Midmar, to Lake Albert Falls, then to Lake Nagle and Lake Inanda (Fig. 8). The Vaal River system does not show such clear trends as the system is massive and has numerous tributaries with very different $\mathrm{Sr}$ characteristics. The present data however correspond very well with the Vaal River data of De Villiers et al. (2000). The data from De Villiers et al. (2000) for the Lower Orange River plots centrally within all the available data for the upstream parts of this river system, possibly indicating that the Lower Orange River composition represents mixing of all the upstream components (Fig. 8).

The Crocodile River system shows much clearer mixing properties. Lake Loskop falls on a mixing line between Lake Bronkhorstspruit and Lake Witbank/Middelburg. Lake Arabie falls on a mixing line between Lake Loskop and Lake Rhenosterkop. This is a precise representation of the field observations. Lake Rhenosterkop, the Elands River and Lake Rust de Winter show the same linear downstream trend as the Mgeni River system. Variation in Sr concentration data in the Crocodile River system is limited. Clear linear mixing trends are difficult to identify.

Land et al. (2000) used element ratios rather than element concentrations for mixing models when investigating a small catchment situated within the Kalix River watershed in northern Sweden. Figure 9 (after Land et al., 2000) shows the ${ }^{87} \mathrm{Sr} /{ }^{86} \mathrm{Sr}$ vs. $\mathrm{Ca} / \mathrm{Sr}$ for the project area. Mixing trends in data from all four large catchments are essentially similar to trends described on the ${ }^{87} \mathrm{Sr} /{ }^{86} \mathrm{Sr}$ vs. $1 / \mathrm{Sr}$ plot (Fig. 8). Figure 10 shows the ${ }^{87} \mathrm{Sr} /{ }^{86} \mathrm{Sr}$ vs. $\mathrm{Cl}^{-} / \mathrm{SO}_{4}{ }^{2-}$ data on a mixing diagram. It includes the possibility of chloride and sulphur from possible anthropogenic pollution sources. Again, mixing trends in data from all four large catchments are essentially similar to trends described on the ${ }^{87} \mathrm{Sr} /{ }^{86} \mathrm{Sr}$ vs. $1 / \mathrm{Sr}$ plot (Fig. 8). Data are however less spread out and mixing relationships are clearer.

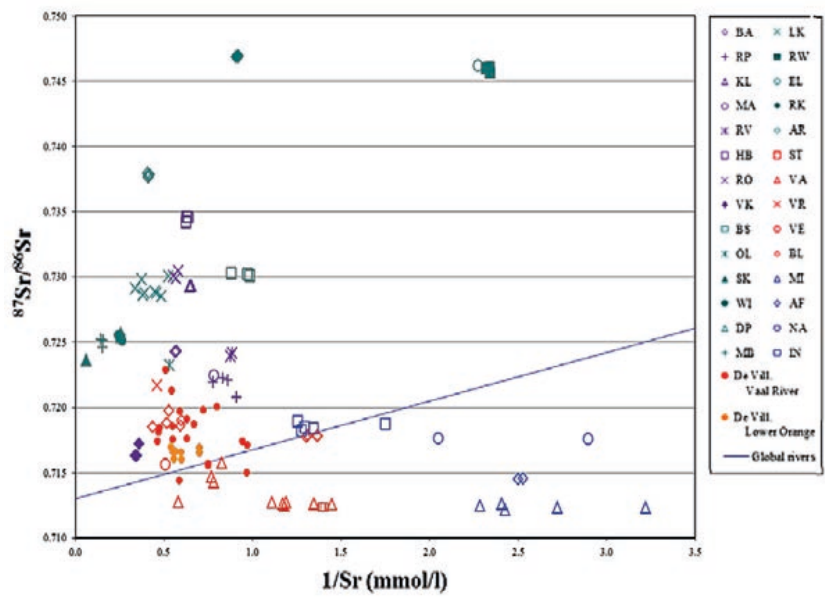

Figure 8

All water data from project area. Orange and Vaal River data from De Villiers et al. (2000). For codes see Table 1.

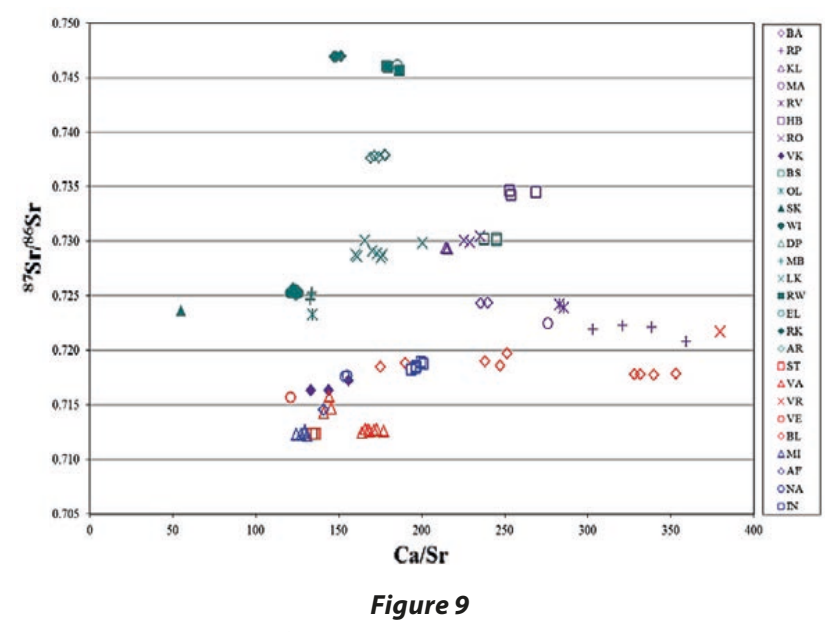

All water data from project area. For codes see Table 1. 


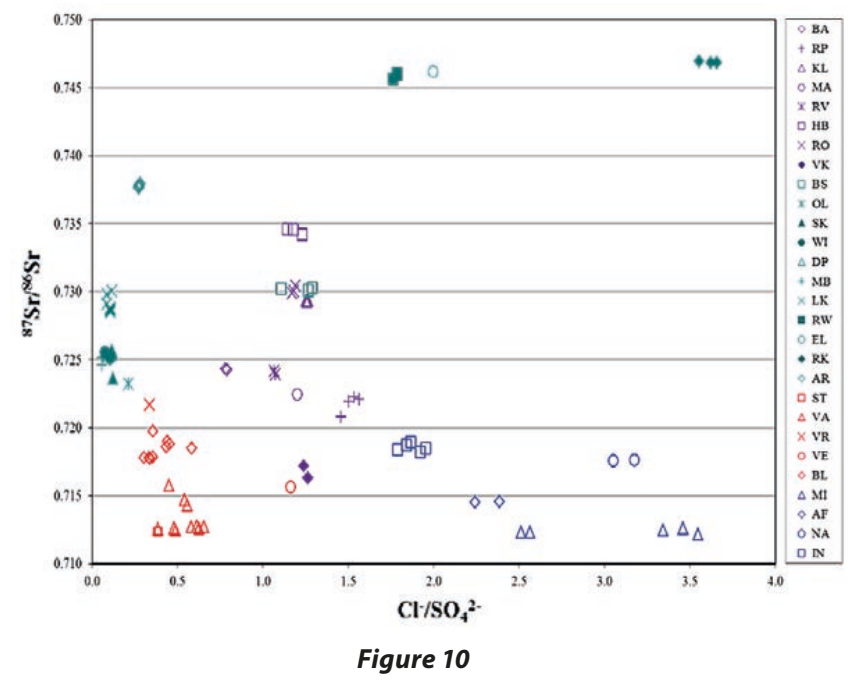

All water data from project area. For codes see Table 1.

\section{CONCLUSIONS}

Sr isotope ratios of water samples were in all cases determined on the dissolved $\mathrm{Sr}$ fraction. The origin of this fraction can therefore be either from the natural weathering of upstream geological units or from upstream anthropogenic sources. An investigation of the Vaal and Orange Rivers by De Villiers et al. (2000) showed that much of the Sr isotope ratio of the river is determined by the isotope ratio of the predominant geological strata in the upper part of the catchment (where active weathering is taking place). In the upper Olifants River system there is certainly ample proof of additions to the river water from mine, municipal or industrial sources. The $\mathrm{Sr}$ isotopic ratios of the water samples were however constant over a 3-year period (2007-2009), suggesting that the main source may be the more consistent geological environment. Anthropogenic Sr sources vary along the course of a river, but individual anthropogenic sources may be more constant over time than expected. Most of the larger fish that were analysed (carp above $4 \mathrm{~kg}$ ) were also older than 5 years (Balik et al., 2006; Sedaghat, 2013) indicating that a relatively constant $\mathrm{Sr}$ source may have been available to them for several years. In larger lakes with only one major inlet the Sr isotope ratio is very constant, even close to the inlet. In large lakes with two major inlets like Lake Vaal or Lake Bloemhof, slight differences may exist between the inlets.

The Sr isotope ratio of fish spine tissue shows a remarkable correlation with the $\mathrm{Sr}$ isotope ratio of the lake water in which these fish lived. It correlates much better than any single element and may therefore be used to establish a link between the fish and lake water. It also shows that the Sr isotope ratio systematics is constant over the multi-year span of the project and that the season in which samples were taken did not contribute any variability. The establishment of a chemical link between fish and lake water provides a forensic tool to eliminate illegal entries at major South African fishing tournaments.

Inter-catchment water transfers are relatively constant and should have a constant influence on the natural water chemistry. Correlating fish to lake water should therefore be possible despite the fact that the water may contain anthropogenic components.

In the Olifants River catchment, Lake Middelburg, Lake Witbank and Lake Doornpoort have a similar Sr isotope ratio, which is distinct from Lake Bronkhorstspruit, primarily due to differences in catchment geology. Lake Loskop, which is downstream from these lakes, has a $\mathrm{Sr}$ isotope ratio between these two extremes, clearly indicating mixing of water from upstream sources. Similarly, Lake Arabie, which is even further downstream, shows a Sr isotope composition between the composition of Lake Loskop and the lakes in the Elands River, again indicating mixing. The $\mathrm{Sr}$ isotope composition of a single lake may therefore be the result of several factors that may give a lake and the fish living within it a distinctive character.

\section{ACKNOWLEDGEMENTS}

The authors would like to acknowledge Bella Honeybourne, the organizing committee of the Three Species Bonanza, EcoCare Trust, Waterlab and the various nature conservation organizations for their support during fieldwork as well as the Council for Geoscience and the University of Johannesburg for financial and technical support.

\section{REFERENCES}

BALIK I, CUBUK H, ÖZKÖK R and UYSAL R (2006) Some characteristics and size of carp (Cyprinus carpio L., 1758) population in the Lake Karamik (Afyonkarahisar/Turkey). Turk. J. Fish. Aquat. Sci. 6 177-122.

BARTON JM, CAIRNCROSS B and MCLACHLAN I (2004) Rb-Sr isotopic and elemental studies of the origin of glauconite in the Permian northern Karoo Coal Fields, South Africa: Evidence for a thermal Mid-Jurassic influence. S. Afr. J. Geol. 107 499-504. http:// dx.doi.org/10.2113/gssajg.107.4.499

BEARD BL and CLARK CM (2000) Strontium isotope composition of skeletal material can determine the birth place and geographic mobility of humans and animals. J. Forensic Sci. 45 (5) 1049-1061. http://dx.doi.org/10.1520/jfs14829j

CAPO RC, STEWART BW and CHADWICK OA (1998) Strontium isotopes as tracers of ecosystem processes: theory and methods. Geoderma 82 (1-3) 197-225. http://dx.doi.org/10.1016/ S0016-7061(97)00102-X

COUNCIL FOR GEOSCIENCE (2011) RSA 1:1000000 geological map. Digital data. Council for Geoscience, Pretoria.

DALAI TK, KRISHNASWAMI S and KUMAR A (2003) Sr and ${ }^{87} \mathrm{Sr} /{ }^{86} \mathrm{Sr}$ in the Yamuna River System in the Himalaya: sources, fluxes, and controls on $\mathrm{Sr}$ isotope composition. Geochim. Cosmochim. Acta 67 2931-2948. http://dx.doi.org/10.1016/ S0016-7037(03)00203-5

DWAF (DEPARTMENT OF WATER AFFAIRS AND FORESTRY, SOUTH AFRICA) (2004) National Water Resource Strategy. $1^{\text {st }}$ edition. Department of Water Affairs and Forestry, Pretoria, South Africa. 259 pp.

DE VILLIERS S, COMPTON JS and LAVELLE M (2000) The strontium isotope systematics of the Orange River, Southern Africa. S. Afr. J. Geol. 103 237-248. http://dx.doi.org/10.2113/1030237

DE VILLIERS S and DE WIT MJ (2007) Source of river water radiogenic strontium: examples from the Archaean granite dominated catchments of Swaziland. S. Afr. J. Geol. 110 349-366. http://dx.doi. org/10.2113/gssajg.110.2-3.349

DOUGLAS GB, GRAY CM, HART BT and BECKETT R (1995) A strontium isotopic investigation of the origin of suspended particulate matter (SPM) in the Murray-Darling River system, Australia. Geochim. Cosmochim. Acta 59 (18) 3799-3815. http://dx.doi. org/10.1016/0016-7037(95)00266-3

EDMOND JM (1992) Himalayan tectonics, weathering processes, and the strontium isotope record in marine limestones. Science $\mathbf{2 5 8}$ 1594-1597. http://dx.doi.org/10.1126/science.258.5088.1594

FAURE G (1986) Principles of Isotope Geology (2 ${ }^{\text {nd }}$ edn). John Wiley and Sons, New York. 589 pp.

FISHER R and STREUBER AM (1976) Strontium isotopes in selected streams within the Susquehanna River catchment. Water Resour. Res. 12 1061-1068. http://dx.doi.org/10.1029/WR012i005p01061 
GALY A, FRANCE-LANORD C and DERRY LA (1999) The strontium isotopic budget of Himalayan Rivers in Nepal and Bangladesh. Geochim. Cosmochim. Acta 63 1905-1925. http://dx.doi. org/10.1016/S0016-7037(99)00081-2

HARRIS N, BICKLE M, CHAPMAN H, FAIRCHIELD I and BUNBURY J (1998) The significance of Himalayan rivers for silicate weathering rates: evidence from the Bhote Kosi tributary. Chem. Geol. 144 205-220. http://dx.doi.org/10.1016/ s0009-2541(97)00132-0

HOPPE KA, KOCH PL, CARLSON RW and WEBB SD (1999) Tracking mammoths and mastodons: Reconstruction of migratory behaviour using strontium isotope ratios. Geology 27 (5) 439-442. http://dx.doi org/10.1130/0091-7613(1999)027<0439:tmamro>2.3.co;2

JORDAAN LJ (2015) Determining the role of catchment geochemistry on the chemistry of water, sediment and fish from impoundments within selected large catchments in South Africa. PhD thesis, Department of Zoology, University of Johannesburg. URL: http:// hdl.handle.net/10210/13873. 281 pp.

JORDAAN LJ, DE WET LPD, RADEMEYER MC and WEPENER $\mathrm{V}$ (2009) The strontium isotope distribution in water and fish within major South African drainage basins. Proceedings of the $13^{\text {th }}$ Yellowfish Working Group Conference. The Federation of Southern African Flyfishers, Sterkfontein Dam, Harrismith, South Africa. $13-15$.

JORDAAN LJ and MARITZ H (2010) Analytical methods 2009 Council for Geoscience analytical chemistry laboratory. Confidential report 2010-0088. Council for Geoscience, Pretoria, South Africa.

JORDAAN LJ AND RADEMEYER MC (2009) Progress report: ST-2007-0955. The chemical interactions between the geological environment and the biological components within large drainage basins. Confidential report 2009-0026. Council for Geoscience, Pretoria, South Africa.

JORDAAN LJ, RADEMEYER MC and DE WET LPD (2006) The use of Strontium isotope ratios in the identification of the specific habitat of Cyprinus carpio. Poster presentation, 2006 Vaal Dam Bonanza, Jim Fouche Resort, South Africa.

KENDAL C, SKLASH MG and BULLEN TD (1995) Isotope tracers of water and solute sources in catchments. In: Trudgill ST (ed) Solute Modelling in Catchment Systems. Wiley and Sons Ltd, New York. 261-303.

KENNEDY BP, KLAUE A, BLUM JD, FOLT CL and NISLOW KH (2002) Reconstructing the lives of fish using Sr isotopes in otoliths. Can. J. Aquat. Sci. 59 925-929. http://dx.doi.org/10.1139/f02-070

LAND M, INGRI J, ANDERSSON PER S and OHLANDER B (2000) $\mathrm{Ba} / \mathrm{Sr}, \mathrm{Ca} / \mathrm{Sr}$ and ${ }^{87} \mathrm{Sr} /{ }^{86} \mathrm{Sr}$ ratios in soil water and groundwater: implications for relative contributions to stream water discharge. Appl. Geochem. 15 311-325. http://dx.doi.org/10.1016/ s0883-2927(99)00054-2

MCCAFFREY LP and WILLIS JP (2001) Distribution of fluoride-rich groundwater in the Eastern and Mogwase regions of the Northern and North-West Provinces. WRC Report No. 526/1/01. Water Research Commission, Pretoria.
MIDDLETON BJ and BAILEY AK (2005) Water Resources of South Africa, 2005 study (WR2005). WRC Report No. TT 380/08. Water Research Commission, Pretoria.

NÉGREL P, PETELET-GIRAUD E and WIDORY D (2004) Strontium isotope geochemistry of alluvial groundwater: a tracer for groundwater resources characterization. Hydrol. Earth Sci. 8 (5) 959-972. http://dx.doi.org/10.5194/hess-8-959-2004

OTIS KJ and WEBER JJ (1982) Movement of carp in the Lake Winnebago system determined by radio telemetry. Technical Bulletin 134. Department of Natural Resources, Madison, Wisconsin.

OUTRIDGE PM, CHENERY SR, BABALUK JA and REIST JD (2002) Analysis of geological Sr isotope markers in fish otoliths with subannual resolution using laser ablation-multicolector-ICP-mass spectrometry. Environ. Geol. 42 891-899. http://dx.doi.org/10.1007/ s00254-002-0596-x

PALMER MR and EDMOND JM (1992) Controls over the strontium isotope composition of river water. Geochim. Cosmochim. Acta 56 (5) 2099-2111. http://dx.doi.org/10.1016/0016-7037(92)90332-D

PENNE CR and PIERCE CL (2006) Habitat use, seasonal distribution, and aggregation of common carp (Cyprinus carpio) in Clear Lake, Iowa. Annual progress. Iowa State University, United States of America.

SEDAGHAT S, HOSEINI SA, LARIJANI M and RANJBAR KS (2013) Age and growth of common carp (Cyprinus carpio Linnaeus, 1759) in Southern Caspian Sea, Iran. World J. Fish Mar. Sci. 5 (1) 71-73.

SABS (SOUTH AFRICAN BUREAU OF STANDARDS) (2010a). SABS Water-Check Group 1, April 2010, Final Report. 14 pp.

SABS (SOUTH AFRICAN BUREAU OF STANDARDS) (2010b) SABS Water-Check Group 1, June 2010, Final Report. 14 pp.

SABS (SOUTH AFRICAN BUREAU OF STANDARDS) (2010c) SABS Water-Check Group 1, October 2010, Final Report. 14 pp.

SABS (SOUTH AFRICAN BUREAU OF STANDARDS) (2010d) SABS Water-Check Group 3, June 2010, Final Report. 28 pp.

SABS (SOUTH AFRICAN BUREAU OF STANDARDS) (2010e) SABS Water-Check Group 3, September 2010, Final Report. 29 pp.

SABS (SOUTH AFRICAN BUREAU OF STANDARDS) (2010f) SABS Water-Check Group 3, December 2010, Final Report. 29 pp.

VAN DER MERWE A (2011) Personal communication, 23 February 2011. Alwyn Van der Merwe, Eskom, South Africa.

VAN DER MERWE NJ, LEE-THORPE JA, THACKERAY JF, HALL-MARTIN A, KRUGER FJ, COETZEE H, BELL RHV and LINDEQUE M (1990) Source-area determination of elephant ivory by isotopic analysis. Nature 36 744-749. http://dx.doi. org/10.1038/346744a 0

VOGEL JC, EGLINGTON BM and AURET JM (1990) Isotope fingerprints in elephant bone and ivory. Nature 346 747-748. http:// dx.doi.org/10.1038/346747a0

WALTHER BD and THORROLD SR (2006) Water not food, contributes the majority of strontium and barium deposited in the otoliths of marine fish. Mar. Ecol. Prog. Ser. 311 125-130. http://dx.doi. org/10.3354/meps311125 